\title{
Digital smile designing, pressing and stratifying ceramic lithium disilicate veneers to rehabilitate dental agenesis: a clinical report
}

\author{
Facetas cerâmicas de dissilicato de litio estratificadas e \\ prensadas para reabilitação de agenesia dental \\ com digital smile design: relato de caso
}

\author{
Jordana Dias MARTINS ${ }^{1}$ iD 0000-0001-5793-681X \\ Camila Moreira LIMA1 ${ }^{1}$ iD 0000-0003-3233-5684 \\ Jean Soares MIRANDA² ID 0000-0001-5379-0155 \\ Fabíola Pêssoa Pereira LEITE ${ }^{1}$ iD 0000-0001-6316-5679 \\ Ricardo TANAKA ${ }^{3}$ iD 0000-0003-0902-7739 \\ Eduardo MIYASHITA ${ }^{4}$ iD 0000-0002-1098-714X
}

\section{ABSTRACT}

This article had the objective of reporting a case of aesthetic rehabilitation with laminated facets from the 14 to the 24 teeth made with IPS E. max Ceram ceramics (Ivoclar-Vivadent), which replaced previous unsatisfactory composite resin restorations in the anterior region. The patient had agenesis of 12 and 22 teeth, making it necessary to anatomize the anterior teeth. A digital smile design was first virtually created and then followed by a diagnostic wax-up. The following was performed in a single day: periodontal surgery using the flapless technique to achieve prosthetic space; teeth preparation; an additional silicone impression; and multiple provisional restorations of bis-acryl composite resins were fabricated. Fourteen days later, in the second session the ceramic veneers were etched with $5 \%$ hydrofluoric acid for 20 s; they received a silane application and a silane heat treatment, then lastly an ultrasonic bath. A universal adhesive was used in combination with a light curing cement. Cementation was performed immediately following an occlusal adjustment. The patient returned for a follow-up appointment another fourteen days after the luting process, in which a further occlusal adjustment was performed, and he reported complete satisfaction with the treatment.

Indexing terms: Esthetic. Anodontia. Mouth rehabilitation.

\footnotetext{
$\boldsymbol{v} \boldsymbol{\nabla} \boldsymbol{v}$
}

1 Universidade Federal de Juiz de Fora, Faculdade de Odontologia. Rua José Lourenço Kelmer, s/n., 36036-900, São Pedro, Juiz de Fora, MG, Brasil. Correspondência para / Correspondence to: JD MARTINS. E-mail: < jordana.d.martins@hotmail.com>.

2 Universidade Estadual Paulista "Júlio de Mesquita Filho", Faculdade de Odontologia. São José dos Campos, SP, Brasil.

3 Universidade de São Paulo, Faculdade de Odontologia. São Paulo, SP, Brasil.

${ }^{4}$ Universidade Paulista, Faculdade de Odontologia. São Paulo, SP. Brasil.

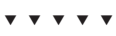

How to cite this article

Martins JD, Lima CM, Miranda JS, Leite FPP, Tanaka R, Miyashita E. Digital smile designing, pressing and stratifying ceramic lithium disilicate veneers to rehabilitate dental agenesis: a clinical report. RGO, Rev Gaúch Odontol. 2019;67:e20190043. http://dx.doi.org/10.1590/1981-8 6372019000433620 


\section{RESUMO}

Este é um relato de caso de reabilitação estética anterior com facetas laminadas dos elementos 14 ao 24 confeccionadas com a cerâmica IPSE.max Ceram (Ivoclar -Vivadent), as quais substituíram facetas de resina composta insatisfatórias dos elementos 13 ao 23. Ressalta-se que o paciente possuía agenesia dos elementos 12 e 22, tornando-se necessária a reanatomização dos dentes anteriores. Inicialmente ocorreu o planejamento digital, seguido pelo enceramento diagnóstico. Foi realizado em consulta única: cirurgia periodontal pela técnica "flapless" para conquista de espaço protético; confecção dos preparos para facetas; moldagem com silicona de adição; e confecção de múltiplos provisórios em resina bisacrilica. Na consulta de cimentação, as peças foram tratadas com ácido fluorídrico 5\% por 20s; silanizadas com Relyxceramic primer (3M ESPE), submetidas ao tratamento térmico; e banho ultrassônico. O sistema adesivo utilizado foi o Single Bond (3M ESPE) associado ao RelyxVenner (3M ESPE). Imediatamente a cimentação foi realizado um ajuste oclusal. Após 14 dias o paciente retornou para uma nova consulta de acompanhamento, na qual foi realizada mais um ajuste oclusal, e relatou total satisfação com o tratamento realizado.

Termos de indexação: Estética. Anodontia. Reabilitação buccal.

\section{INTRODUCTION}

The constant search for a harmonious and aesthetic smile elevates the level of demand and expectation of our patients. They are aiming for more conservative procedures and results which are increasingly aesthetically predictable, which also restore form and function [1-3]. Although restorations have a strong aesthetic appeal which enables correct teeth with color alteration, shape, position, contour and alignment, they should also restore occlusal function, reestablish contact and give occlusion guides [4]. Dentists have the challenge of achieving success in both aspects and still meet the expectations of patients [2].

Agenesis of the upper lateral incisors is a dental anomaly that represents a significant clinical problem and is a good example of a case that needs aesthetic and functional restoration [5]. Correct case planning is necessary in order to perform effective oral rehabilitation, and using photographs is fundamental to support the treatment plan which can then be used for Digital Smile Design (DSD), thereby allowing facial, smile, periodontal tissue and teeth analysis through extra and intraoral digital photographs. The DSD method can also help improve the interaction between dentists and patients, enabling treatment prediction and a critical analysis of the planning for both $[6,7]$.

In view of the numerous restorative techniques capable of mimicking natural teeth, ceramic veneers are known for their longevity, color stability and biocompatibility. In some cases, they can be also minimally invasive, and even without the need for dental preparation, as some ceramics such as lithium disilicate enable the performance of thin restorations $(0.1$ to $0.7 \mathrm{~mm})[3,8,9]$.

Thus, aesthetic and functional restoration as well as maintenance of the biological integrity of the patient through ceramic restorations can be achieved by means of a correct diagnosis and reverse treatment planning, which influences the type of preparation for choosing the rehabilitation material, thereby enabling predictable results and facilitating its clinical execution [1,10-12].

In view of this context, this paper aims to present a clinical case report of upper lateral incisor agenesis rehabilitated with pressed and stratified lithium disilicate ceramics, describing the planning and execution of thin ceramic veneers for functional and aesthetic rehabilitation of elements 14 to 24 .

\section{CASE REPORT}

A 25-year-old male patient had a desire to improve the aesthetics of his smile. A clinical examination revealed agenesis of the upper lateral incisors (teeth 12 and 22). These absences had previously been corrected ten years before with orthodontic treatment to reduce interdental spaces and direct facet type restorations in composite resins on the upper central incisors and canines (teeth $11,21,13$ and 23). However, it was clinically possible to observe the presence of stains at the interface of the resin with the teeth, which made the restorations aesthetically deficient, indicating their replacement (figure 1).

An extra and intraoral photograph protocol was performed for digital smile planning (DSD), upon which the case planning and the diagnostic wax-up was based (figure 2). However, it was impossible to perform a mock-up directly in the patient's mouth to approve the planning due to the need to perform wear on the gypsum model teeth to perform harmonic waxing. Therefore, this procedure was only performed digitally. 

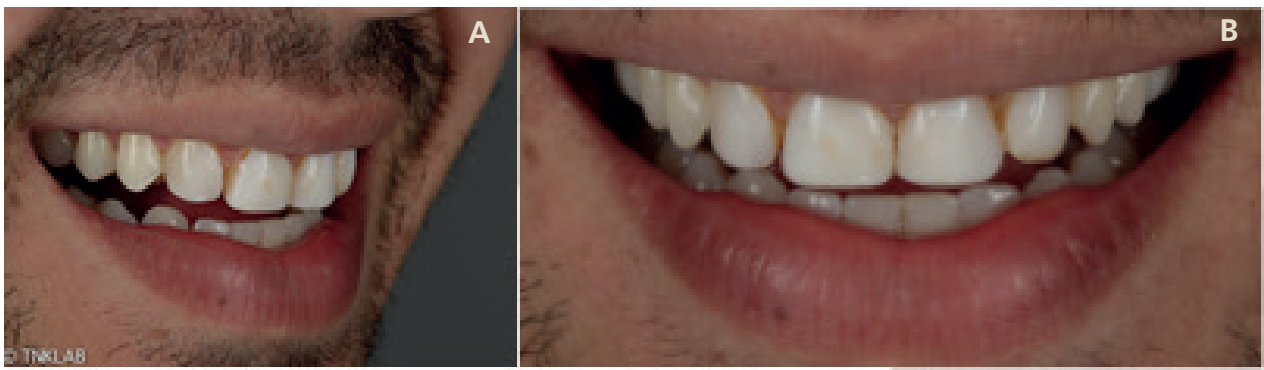

B

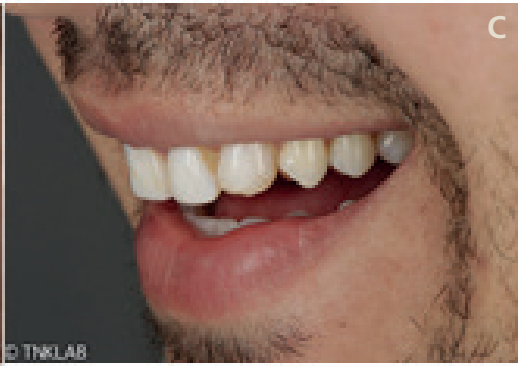

Figure 1. Initial facial extrabuccal photographs of the patient in which it is possible to observe the staining of adhesive interfaces in the lateral view (A, C) and aesthetic disharmony in the frontal view (B). São Paulo, 2017.
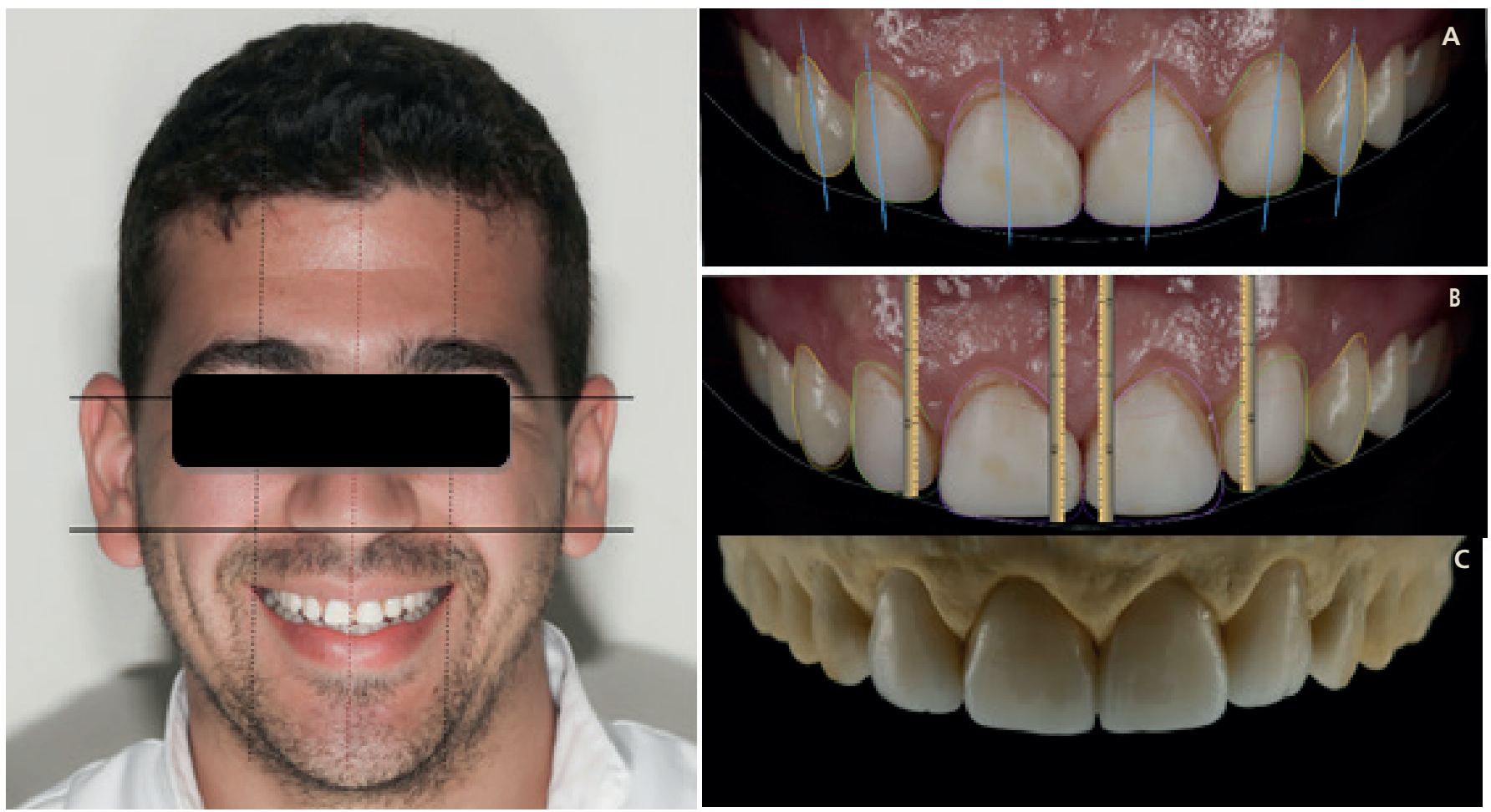

Figure 2. Vertical and horizontal lines symmetrically distributed across the patient's face to guide digital planning (DSD) (A). This design was also used to establish the new vertical alignment (B) and teeth dimensioning. This digital planning was then used as a guide for the diagnostic wax-up of the gypsum model (D). São Paulo, 2017.

Although the mock-up in bis-acryl composite resins (Protemp 4, 3M ESPE, St Paul, MN, USA) was not used to approve aesthetic planning, it guided gingivoplasty and dental preparations during these procedures. With the digital protocol, it was possible to measure the exact amount of gingival tissue to be remodeled by gingivoplasty performed with ultrasonic tips (T1S, CV Dentus, São José dos Campos, SP, Brazil) by the flapless technique, reaching maximum symmetry and aesthetics. After the gingival plastic, the preexisting restorative composite resin under the anterior teeth was removed and preparations were made for conventional veneers in the central and upper canines, while the premolars were prepared in a more conservative way so that ultra-thin laminates veneers could be made (figure 3).

In the same session, arcade impressions were made using a retractor wire \#0 (Ultrapak, Ultradent, Indaiatuba, $\mathrm{SP}$, Brazil) and an astringent gingival spacing paste (3M ESPE, St Paul, MN, USA) which was removed with air and water jet before inserting the additional silicone paste 

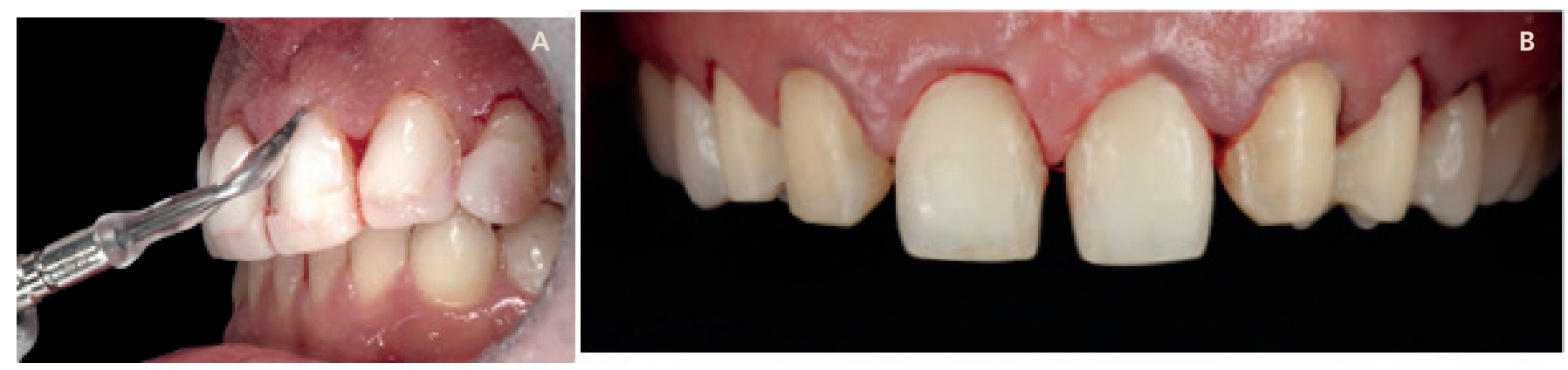

Figure 3. Genvivoplasty performed with an ultrasonic tip to achieve adequate gingival tissue aesthetics in the cervical teeth (A). Dental preparations (wear) executed for manufacturing ceramic laminates (B). São Paulo, 2017.

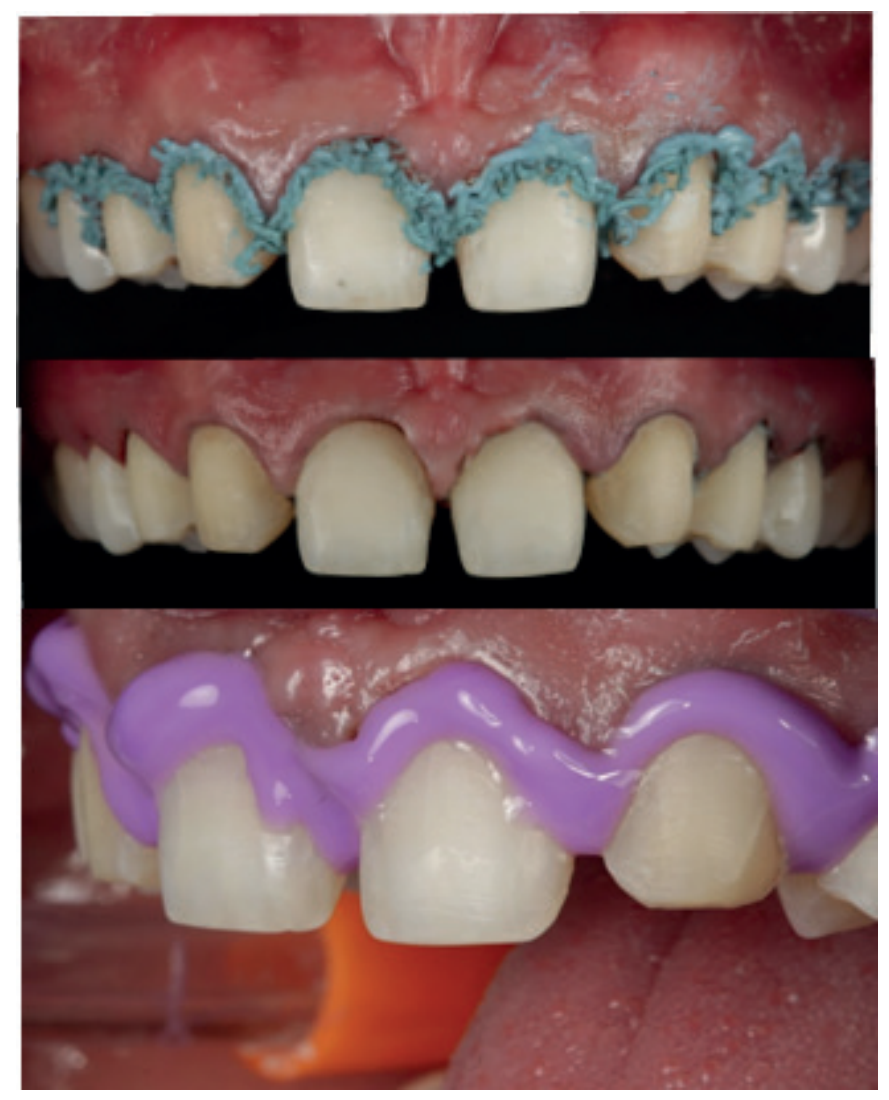

Figure 4. Placement of retractor wire (Ultrapak, Ultradent, Indaiatuba, SP, Brazil) and astringent paste (3M ESPE, St Paul, MN USA) (A) to generate gingival spacing (B) which would allow better detailing by adding silicone impression (Express XT3M ESPE, St Paul, MN, USA) (C). São Paulo, 2017.

(Express XT3M ESPE, St Paul, MN, USA) into the properly dried teeth preparations (figure 4). After substrate color pick-up and color choice for the veneer restorations, united temporary restorations were prepared from teeth 14 to 24 with the bis-acryl composite resins in color A2 (figure 5).
The laboratory phase began from that point, in which a type IV superior gypsum model with alveolar troches and a lower model were put in a semi-adjustable articulator joint. The waxing process was initiated to obtain pressed lithium disilicate slides (Ingot LT A2e-max PRESS, Ivoclar Vivadent, Schaan, Liechtenstein) and stratified veneers with fluorapatite ceramics (e-max Ceran Ivoclar Vivadent, Schaan, Liechtenstein).

The veneer restorations were ready fourteen (14) days later, and the luting process began with the aesthetic test which was approved by the patient and the professionals involved in the case. The veneers were treated with $5 \%$ hydrofluoric acid for 20s, silanized with RelyX ceramic primer (3M ESPE, St Paul, MN, USA), subjected to silane heat treatment with a hair dryer in the hot air function and then submersed in a 5 min ultrasonic bath. The cementation was performed by two veneers at a time with a light-cured cement (RelyX Veneer, 3M ESPE, St Paul, MN, USA) associated with Single Bond Universal (3M ESPE, St Paul, MN, USA) after choosing the color with the try-in pastes of the same kit (figure 6).

A fifteen-day follow-up was performed, the occlusal adjustment was refined, and the patient reported complete satisfaction with the aesthetic and functional rehabilitation.

The present case was performed with the consent of the patient, and he signed the patient Informed Consent Form.

\section{DISCUSSION}

Ceramic veneers are currently routinely used for rehabilitating anterior teeth in purely aesthetic cases as 


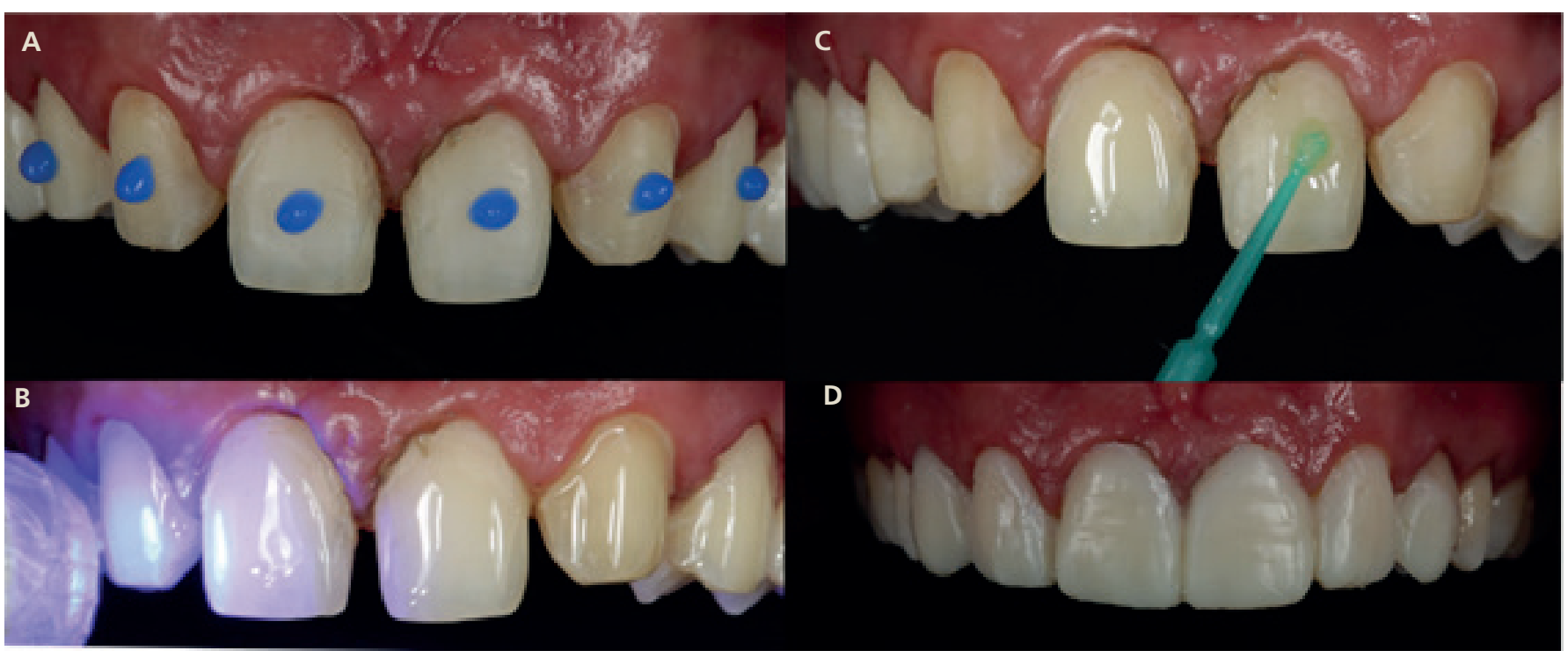

Figure 5. 35\% phosphoric acid (Ultra Etch IndiSpense, Ultradent) etching was made at just one point in each prepared tooth (A) to perform the adhesive placement at only that conditioned point (B), the light curing was performed (C) and the application of the bis-acryl composite resins (Protemp 4, 3M ESPE, St Paul, MN USA) with an additional silicone mock-up for provisional restoration execution. São Paulo, 2017.

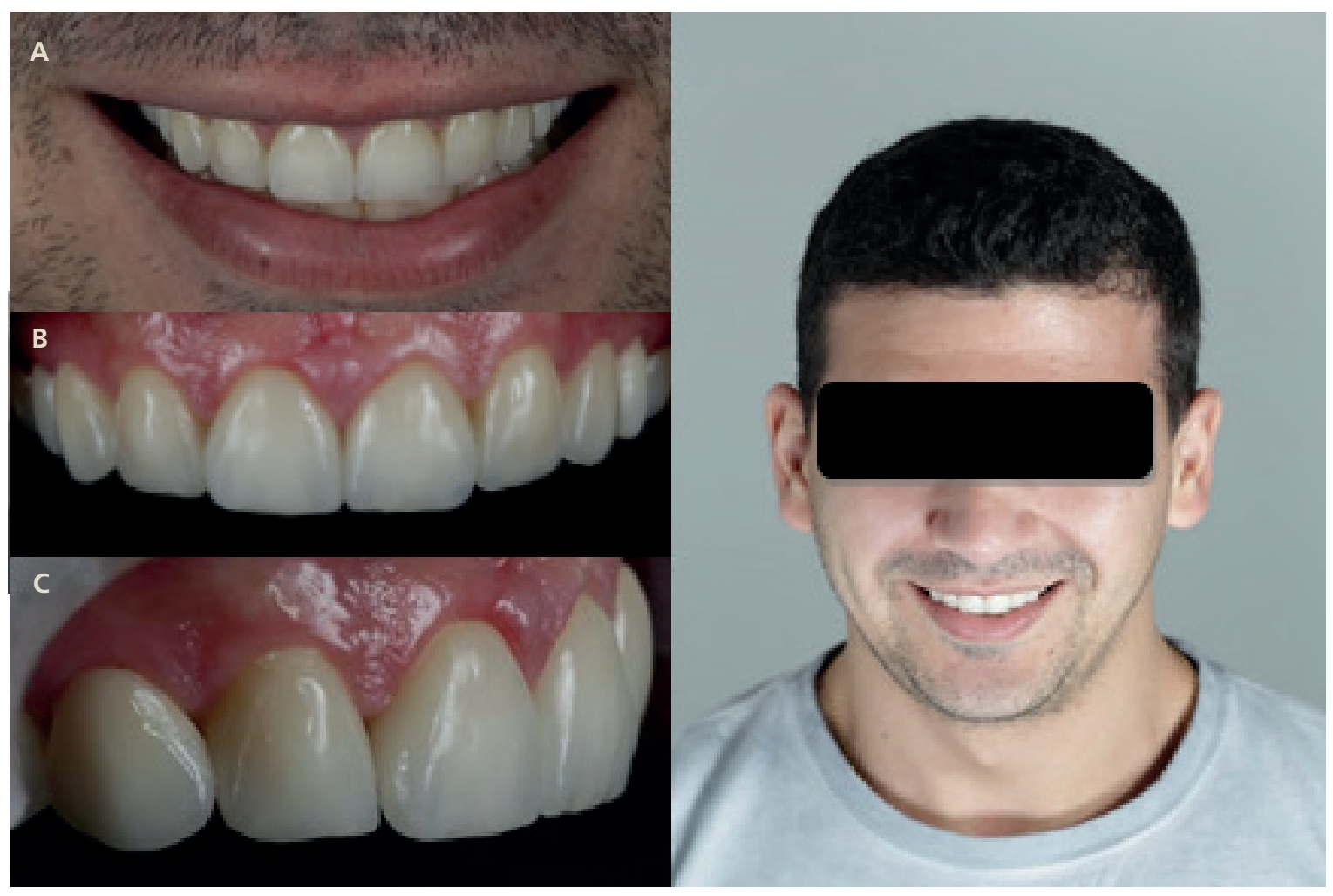

Figure 6. Extra ( $A, D)$ and intrabuccal photographs $(B, C)$ after the luting process, illustrating aesthetic harmony allied to the occlusal function and patient's satisfaction. São Paulo, 2017.

well as in functional agenesis corrections, the presence of diastema, small dental alignments, fractures and substitutions of deficient resin restorations in anterior teeth
$[10,13,14]$. This high amount of application is due to the fact that the majority of veneer cases require little invasive preparation, preserving greater enamel thickness that 
provides an increase in the predictability. This occurs due to higher bond strength of the indirect prosthesis with the adhesive system and the dental enamel when compared to the dentin $[1,15,16]$.

However, in order to achieve success in restorations, a correct diagnosis and adequate treatment planning are necessary which consider both the aesthetic and functional parameters $[13,17]$. This planning can include digital steps such as Digital Smile Design (DSD) which allows aesthetic planning through drawings and reference lines in extra and intraoral photographs6. This should be followed by a wax-up, which helps present the case to the patient and guides the dental wear during the preparation, and which can be performed on a mock-up made with the waxed model $[3,7,10,18]$. The protocol for this type of planning broadens the diagnostic view and helps the professional team members to measure treatment limitations and risk factors, provides greater treatment predictability, and facilitates communication among the team members [7].

As in the case described above, it is common to note the need to perform gingival plastic during the digital planning. In cases of fine or intermediate phenotypes, this surgical procedure can be performed without flaps (flapless) via the gingival sulcus with the use of ultrasonic tips and chisel; a fact that enables maintaining the periosteum and blood supply, thus reducing precocious bone resorption and contributing to the scar tissue process [19]. Therefore, the postoperative period becomes more comfortable and faster for the patient.

Various materials such as composite resins and dental ceramics are available for aesthetic restorations of the anterior teeth [12]. In this case it is possible to note, as reported in the literature, limited longevity of the direct facets of composite resin due to discoloration, wear, staining and marginal infiltration of the resin [13,20-22]; facts that made ceramic restorations a better indication $[6,23]$.

Among ceramic materials that can be highlighted are feldspathic ceramics and the base of lithium disilicate ceramics to make veneer restorations. The lithium disilicate-based system may involve total or partial crown restorations, fixed prostheses, crowns on implants, and more recently ceramic facets. It is important to emphasize that the material's thickness, stratification and cement used will interfere with the longevity and success of the treatment. Restorations based on lithium disilicate still have good biocompatibility, compressive strength, thermal conductivity similar to dental tissues, color stability, and especially high potential to simulate the appearance of dental elements, having a similar refraction index to that of dental enamel [24-30].

Pressed lithium disilicate was chosen in this case report because it presents good aesthetic and mechanical properties, even in a smaller thickness, obtaining a satisfactory result after the stratification and adhesive cementation [7,31-34].

Silane heat treatment was performed with hot air as a step in the adhesive cementation process. Performing this procedure demonstrably increases the bond strength of the ceramic with the resin cement [35]. This is due to the elimination of alcohol, water and other by-products from the ceramic surface. In addition, the heat treatment helps complete the condensation reaction between silicate and silane, making it more effective and stable [35-37].

The main advantage of the approach presented herein is aesthetic rehabilitation, and consequently anatomization of the smile, using a minimally invasive technique in a short period, even with the performance of gingival plasticity. After this plasticity and dental wear, a provisional bis-acryl composite resin was used during the preparation period of the pieces, which also enabled the patient to adapt to the new anatomy and dental occlusion. The case simplicity (digital planning and minimum preparation) accelerated the workflow; however, the technique required attention and precision, especially during the dental preparation with the material choice and with the luting procedure because the veneer restorations are thin. Nevertheless, as supported by the literature, it was noted that ceramic veneers are capable of satisfactorily replacing direct composite resin restorations within the biomimetic requirements, saving dental tissues and restoring aesthetics.

\section{CONCLUSION}

In performing the present case, it was concluded that ceramic veneers are a possibility for conservative and successful treatment of smile anatomization in patients with dental agenesis using careful treatment planning. As a result, a satisfactory, functional and aesthetic rehabilitation of the patient was possible. 
Collaborators

JD MARTINS, development and elaboration of the manuscript. CM LIMA, development and elaboration of the manuscript. JS MIRANDA, manuscript analyses. FPP MILK, case study development. R TANAKA: case study development. AND MIYASHITA, case study development.

\section{REFERENCES}

1. Morita RK, Hayashida MF, Pupo YM, Berger G, Reggiani RD, Betiol EA. Minimally invasive laminate veneers: clinical aspects in treatment planning and cementation procedures. Case Rep Dent. 2016;2016:1839793. http://dx.doi.org/10.11 55/2016/1839793

2. Paolucci B, Calamita M, Coachman C. Visagism: the art of dental composition. Quintess Dent Technol. 2012;1-14.

3. Magne P. Composite resins and bonded porcelain: the postamalgam era? J Calif Dent Assoc. 2006;34(2):135-47.

4. Zavanelli AC, Zavanelli RA, Mazaro JVQ, Santos D, FálconAntenucci RM. Tratamento cosmético com lentes de contato e laminados cerâmicos. Arch Health Invest. 2015;4(3):10-17.

5. Krassnig M, Fickl S. Congenitamente faltando incisivos laterais - uma comparação entre as abordagens restauradora, implante e ortodôntica. Dent Clin North Am. 2011;55(2):283-99. http://dx.doi.org/10.1016/ j.cden.2011.01.004

6. Meereis $C T$, de Souza GB, Albino LG, Ogliari FA, Piva E, Lima GS. Digital smile design for computer-assisted esthetic rehabilitation: two-year follow-up. Oper Dent. 2016;41(1):E13-22. http://dx.doi.org/10.2341/14-350-S

7. Pimentel W, Teixeira ML, Costa PP. Predictable outcomes with porcelain laminate veneers: a clinical report. J Prosthod. 2016;25:335-340. https://doi.org/10.1111/jopr.12413

8. Azer SS, Rosenstiel SF, Seghi RR, Johnston WM. Effect of substrate shades on the color of ceramic laminate veneers. J Prosthet Dent. 2011;106(3):179-83. doi: 10.1016/S00223913(11)60117-0

9. Walter RD, Raigrodski AJ. Clinical considerations for restoring mandibular incisors with porcelain laminate veneers. J Esthetic Restor Dent. 2008;20(4):276-81. http://dx.doi.org/10.1111/ j.1708-8240.2008.00192.x

10. Cabral G, Miranda JS, Sato TP, Penteado M. Reabilitação estético funcional: conjugação de restaurações em resina direta, laminados ultrafinos e onlays cerâmicas. Prótese News. 2017;3(4):436-42.

11. Vishwambaran M, Londhe SM, Kumar V. Conservative and esthetic management of diastema closure using porcelain laminate veneers. Med J Armed Forces. 2014;30:1-2. http:// dx.doi.org/10.1016 / j.mjafi.2014.08.014

12. Prajapati $P$, Sethuraman $R$, Naveen $Y G$, Patel JR. Indirect laminate veneer: a conservative novel approach. BMJ Case Rep. 2013 Aug 23;2013. pii: cr2013010295. http://dx.doi. org/10.1136/bcr-2013-010295
13. Rotoli BT, Lima DA, Pini NP, Aguiar FH, Pereira GD, Paulillo $\mathrm{LA}$. Porcelain veneers as an alternative for esthetic treatment: clinical report. Oper Dent. 2013;38(5):459-66. http://dx.doi. org/10.2341/12-382-T

14. Strassler HE. Minimally invasive porcelain veneers: indications for a conservative esthetic dentistry treatment modality. Gen Dent. 2007;55(7):686-94.

15. Alavi AA, Behroozi Z, Nik Eghbal F. The shear bond strength of porcelain laminate to prepared and unprepared anterior teeth. J Dent (Shiraz). 2017;18(1):50-55.

16. Magne P, Bruzi G, Carvalho AO, Giannini M, Maia HP. Evaluation of an anatomic dual-laminate composite resin shade guide. J Dent. 2013;41(Suppl 3):e80-6. http://dx.doi. org/10.1016/j.jdent.2013.05.001

17. Archangelo CM, Rocha EP, Martin Jr M, Anchieta RB. Laminate veneers: a review and clinical case. Int J Clin Dente Sci. 2011; 4(3):171-179.

18. Moretto G, Pupo YM, Bueno AL, Araujo FO. Prosthetic rehabilitation of a patient with gastroesophageal reflux disease: five-year follow-up. Oper Dent. 2016;41(2):132-7. http://dx.doi.org/10.2341/14-297-O

19. Miyashita E, Oliveira GG. Odontologia estética: os desafios da clinica. São Paulo: Napoleão Ltda.; 2014.

20. Gresnigt MM, Kalk W, Ozcan M. Randomized clinical trial of indirect resin composite and ceramic veneers: up to 3-year follow-up. J Adhes Dent. 2013;15(2):181-90. http://dx.doi. org/10.3290/j.jad.a28883

21. Gresnigt MM, Kalk W, Özcan M. Longevidade clínica de lâminas cerâmicas laminadas ligadas a dentes com e sem restaurações compostas existentes até 40 meses. Clin Oral Investig. 2013;17(3):823-32. http://dx.doi.org/10.1007 / s00784-012-0790-5

22. Peumans M, De Munck J, Fieuws S, Lambrechts $P$, Vanherle G, Van Meerbeek B. Aprospective ten-year clinical trial of porcelain veneers. J Adhes Dent. 2004;6(1):65-76.

23. Conrad HJ, Seong WJ, Pesun IJ. Current ceramic materials and systems with clinical recommendations: a systematic review. J Prosthet Dent. 2007;98(5):389-404.

24. Apel E, Deubener J, Bernard A, Höland M, Müller R, Kappert $\mathrm{H}$, et al. Phenomena and mechanisms of crack propagation in glass-ceramics. J Mech Behav Biomed Mater. 2008;1(4):313-25. http://dx.doi.org/10.1016/j.jmbbm.2007.11.005

25. Johansson C, Kmet G, Rivera J, Larsson C, Vult Von Steyern P. Fracture strength of monolithic all-ceramic crowns made of high translucent yttrium oxide-stabilized zirconium dioxide compared to porcelain-veneered crowns and lithium disilicate crowns. Acta Odontol Scand. 2014;72(2):145-53. http:// dx.doi.org/10.3109/00016357.2013.822098

26. Ma L, Adivinha PC, Zhang Y. Propriedades de carga de mínima invasive dissociações monolíticas de dissilicato de lítio e zircônia: elementos finitos e análises teóricas. Mater Dent. 2013;29(7):742-51. http://dx.doi.org/10.1016 / j.dental.20 13.04.004.

27. Mazaro JVQ, Zavanelli AC, Pellizzer EP, Verri FR, FalcónAntennucci RM. Considerações clínicas para restauração 
da região anterior com facetas laminadas. Rev Odontol Araçatuba. 2009; 30(1):51-54.

28. Silva NRFA, Bonfante EA, Martins LM, Valverde GB, Thompson $V P$, Ferencz JL, et al. Reliability of reduced-thickness and thinly veneered lithium disilicate crowns. J Dental Res. 2012;91(3): 305-310. http://dx.doi.org/10.1177/0022034511433504

29. Zhang Y, Lee JJ, Srikanth R, Lawn BR. Edge chipping and flexural resistance of monolithic ceramics. Dent Mater. 2013;29(12):1201-8. http://dx.doi.org/10.1016/j.dental.2013. 09.004

30. Zhao K, Wei $Y R$, Pan $Y$, Zhang XP, Swain MV, Guess PC. Influence of veneer and cyclic loading on failure behavior of lithium disilicate glass-ceramic molar crowns. Dent Mater. 2014;30(2):164-71. http://dx.doi.org/10.1016/j.dental

31. Re D, Augusti G, Amato M, Riva G, Augusti D. Esthetic rehabilitation of anterior teeth with laminates composite veneers. Hindawi Publishing Corporation Case Reports in Dentistry. 2014;9p. http://dx.doi.org/10.1155/2014/849273

32. Alghazzawi TF, Lemons J, Liu PR, Essig ME, Janowski GM. The failure load of CAD/CAM generated zirconia and glass-ceramic laminate veneers with different preparation designs. J Prosthet Dent. 2012;108(6):386-93. http://dx.doi. org/10.1016/S0022-3913(12)60198-X
33. Mangani F, Cerutti A, Putignano A, Bollero R, Madini L. Clinical approach to anterior adhesive restorations using resin composite veneers. Eur J Esthet Dent. 2007;2(2):188-209.

34. Coachman C, Calamita M. Digital smile design: a tool for treatment planning and communication in esthetic dentisty. Quintess Dent Technol. 2012;35:103-111.

35. de Carvalho RF, Martins ME, de Queiroz JR, Leite FP, Ozcan $M$. Influence of silane heat treatment on bond strength of resin cement to a feldspathic ceramic. Dent Mater J. 2011;30(3):392-7.

36. Baratto SSP, Spina DRF, Gonzaga CC, Cunha LF. Silanated surface treatment: effects on the bond strength to lithium disilicate glass-ceramic. Braz Dental J. 2015;26(5):474-477.

37. Aguiar TR, Barbosa WFS, Francescantonio M, Giannin M. Effects of ceramic primers and postsilanization heat treatment on bond strength of resin cement to lithium disilicatebased ceramic. Appl Adhes Sci. 2016;4:20.

Received on: 6/11/2018

Final version resubmitted on: 18/12/2018

Approved on: 8/2/2019 